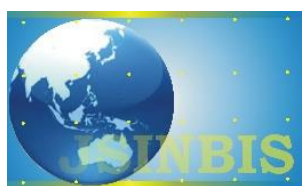

\title{
Pemanfaatan Social Network Analysis Untuk Menganalisis Kolaborasi Komunikasi Pada Balai Perikanan Budidaya Laut Ambon
}

\author{
Ariyanto Latupeirissa ${ }^{*}$, Eko Sediyono, Ade Iriani \\ Magister Sistem Informasi, Universitas Kristen Satya Wacana \\ Naskah Diterima : 21 Mei 2019; Diterima Publikasi : 19 September 2019 \\ DOI : 10.21456/vol9iss2pp121-132
}

\begin{abstract}
Marine aquaculture center-Ambon (Balai Perikanan Budidaya Laut/BPBL-Ambon) is a technical implementing unit under supervision of Directorate General of Aquaculture, Ministry of Maritime Affairs and Fisheries, Republic of Indonesia. Based on report of government's internal control system (Sistem Pengendalian Intern Pemerintah/SPIP) specifically at the third quarter, some crucial organizational disadvantages have been identified in BPBL-Ambon, particularly related to the communication and coordination between divisions and technical staffs. To deal with this problem, there is a need to analyze and map the roles of interactions between employees in social networks. This study aims to analyze the patterns of interaction between staffs in the social networks. In this work, social network analysis (SNA) was used, which is based on formal and informal interactions on BPBL-Ambon, enabling to identify the key actors potentially able to act as alternative actors for information access to facilitate communication. The collection of individual data, as well as formal and informal interactions, was carried out using questionnaire and interview, involving entire population (saturation sampling). The collected data were then filetered and tabulated symmetric matrix, as preliminary steps for analysis following exported. SNA approach focuses on determining degree centrality, closeness centrality, and betweenness centrality. As a result, our experimental data suggested that most divisions alreadyshowed an appreciable collaboration in terms of communication; however, the remaining divisions showed 0 value in terms of their relationship with other divisions. Based on these findings, we could solve the problem through acting the alternative actors having the highest indegree value apart from stakeholders from a division capable of acting as alternative sources of information. The involvement of alternative actors could be a meaningful attempt in order to solve communication and coordination problems present in BPBL-Ambon.
\end{abstract}

Keywords: Social Network Analysis, Collaboration, Alternatif Aktor

\begin{abstract}
Abstrak
Balai Perikanan Budidaya Laut-Ambon (BPBL Ambon) adalah Unit Pelaksana Teknis yang berada di bawah Direktorat Jenderal Perikanan Budidaya, Kementrian Kelautan dan Perikanan. Berdasarkan Laporan Sistem Pengendalian Interm Pemerintah (SPIP) Triwulan III pada BPBL Ambon menjelaskan bahwa kurangnya komunikasi dan koordinasi dari beberapa divisi dan pelaksana kegiatan diakui sebagai salah satu masalah yang terdapat pada BPBL Ambon. Agar dapat menyelesaikan permasalahan ini diperlukan metode yang mampu menganalisis dan memetakan peran serta interaksi para pegawai dalam jaringan sosial. Penelitian ini bertujuan untuk menganalisis pola interaksi dari jaringan dalam rangka penyelesaian masalah komunikasi dan koordinasi. Penggunaan social network analysis (SNA) berdasarkan interaksi formal dan informal pada BPBL Ambon diharapkan dapat memberikan hasil analisis penelitian berupa aktor-aktor yang mampu menjadi alternatif aktor dalam rangka akses informasi dalam upaya melancarkan komunikasi. Data individu serta interaksi formal dan informal mereka dalam jaringan di dapat dengan metode kusioner dan wawancara dengan sampel keseluruhan anggota populasi (Saturation Sampling). Data tersebut kemudian disaring dan ditabulasikan kedalam metriks simetris sehingga dapat diekspor untuk dianalisis. Proses analisis menggunakan metode SNA untuk mengukur sentralitas antar aktor, yaitu degree centrality, closeness centrality, betweenness centrality. Dari penelitian ini dipahami bahwa sebagian besar divisi telah melakukan kolaborasi komunikasi namun ada beberapa divisi yang memiliki nilai 0 dalam hal relasinya dengan deivisi lain. Dari temuan ini diperlukan solusi, Alternatif aktor yang merupakan Aktor yang memiliki nilai indegree tertinggi selain pemangku kepentingan dari suatu divisi dapat dijadikan sebagai aktor alternatif sumber informasi. Hal ini dapat menjadi solusi yang dapat menyelesaikan masalah komunikasi dan koordinasi dari BPBL Ambon.
\end{abstract}

Kata kunci : Analisis Jaringan Sosial; Kolaborasi; Alternatif Aktor.

*) Penulis korespondensi: arilatupeirissa@yahoo.com 


\section{Pendahuluan}

Komunikasi memiliki peran yang penting dalam hubungan manusia, baik antar individu ataupun yang berada dalam organisasi. Dengan adanya komunikasi yang baik dalam sebuah organisasi, maka organisasi tersebut dapat berjalan dengan lancar untuk mencapai tujuannya (Pangestu, 2015).

Adapun Organisasi sendiri ialah merupakan suatu sistem sosial dari sekelompok individu yang bekerjasama untuk mencapai tujuan bersama melalui jenjang hierarki dengan adanya pembagian kerja (Soemirat et al., 2016). Dalam proses berorganisasi proses pertukaran pesan sering terjadi diantara orangorang yang menduduki posisi atau peranan dalam organisasi. Pertukaran pesan ini dinamakan dengan jaringan komunikasi (Muhammad, 1995). Melalui jaringan komunikasi, dapat dilihat jalur komunikasi antara internal organisasi yang sangat dapat membantu melihat keefisienan komunikasi organisasi.

Peneliti melihat salah satu organisasi yang menarik untuk dilihat jaringan komunikasinya adalah Balai Perikanan Budidaya Laut-Ambon (BPBL Ambon). BPBL Ambon adalah Unit Pelaksana Teknis yang berada di bawah Direktorat Jenderal Perikanan Budidaya, Kementrian Kelautan dan Perikanan. (Rencana-Strategis-Perubahan-BPBLA., 2017).

Berdasarkan Laporan Sistem Pengendalian Interm Pemerintah (SPIP) Triwulan III pada BPBL Ambon menjelaskan bahwa kurangnya komunikasi dan koordinasi dari beberapa divisi dan pelaksana kegiatan berdampak terhadap kurangnya disiplin pencatatan barang persediaan dari divisi-divisi produksi yang berakibat pada keterlambatan pencatatan barang persedian di Sistem Informasi Manajemen dan Akuntansi Barang Milik Negara (SIMAK-BMN). Masalah komunikasi dan koordinasi dari beberapa divisi disebabkan oleh delay informasi yang dilakukan oleh pemangku kepentingan /stakeholder. Hal ini menjadikan kinerja dari pada BPBL Ambon menjadi tidak efisien, dikarenakan dalam upaya penyelesaian suatu tugas diperlukan pengecekan rutin dan berkala dari atau terhadap pemangku kepentingan satu ke pemangku kepentingan yang lain agar nantinya tidak mengalami keterlambatan. Hal ini disadari sebagai suatu masalah yang terjadi pada BPBL Ambon (SPIP, 2017).

Penelitian menggunakan SNA (Social Network Analysis) sebenarnya sudah dilakukan sejak lama untuk menggambarkan atau memetakan sebuah jaringan sosial. SNA sendiri adalah suatu ilmu yang mempelajari hubungan antar satu unit entitas dengan unit entitas lainnya dengan bantuan teori graf (Tsvetovat, dan Kouznetsov, 2011). Metode dan teknik SNA dipilih karena SNA merupakan metode yang dapat memberikan gambaran atau visualisasi hubungan dalam jaringan, karena metodi SNA menempatkan para pegawai sebagai aktor (node) dan links sebagai relasi atau hubungan antara para aktor tersebut (Eriyanto, 2014). Metode SNA juga mampu menganalisis dan memetakan pola tersembunyi maupun yang ada didalam interaksi dengan demikian SNA merupakan metode yang tepat dalam rangka menganalisis arus informasi serta hubungan dalam jaringan (Iriani, 2013). Selain pola tersembunyi dari interaksi, pengukuran tentang kolaborasi juga perlu dilakukan untuk dapat mengidentifikasi, menjelaskan dan melihat tingkat keterlibatan aktor serta dampaknya terhadap komunitas (Salamati and Soheili, 2016).

Berdasarkan latar belakang tersebut, maka penelitian ini dilakukan dengan tujuan untuk menganalisis kolaborasi informasi dari jaringan sosial BPBL Ambon dengan menggunakan SNA untuk memvisualisasikan hubungan antar tiap individu yang berada dalam jaringan berdasarkan pola interaksi formal dan informal. Hal ini dilakukan dalam rangka menyelesaikan masalah komunikasi dan koordinasi dari beberapa divisi dan pelaksana kegiatan.

Penelitian ini berfokus pada kolaborasi informasi antar pegawai pada BPBL Ambon. Analisis kolaborasi diperuntukkan untuk mengetahui jalur serta hubungan kolaborasi informasi antar aktor. Hal ini dilakukan agar nantinya dapat diketahui peranan dari tiap aktor mulai dari aktor penting seperti pemangku kepentingan hingga aktor yang memiliki akses informasi seperti halnya pemangku kepentingan, sehingga informasi yang biasanya didapati melalui pemangku kepentingan dari tiap divisi dapat diakses melalui jalur alternatif seperti aktor yang juga memiliki peranan atau pengaruh sosial dalam jaringan. Aktor-aktor tersebut nantinya dapat direkomendasi sebagai alternatif aktor dalam upaya akses informasi dari tiap-tiap divisi pada BPBL Ambon. Hal ini diharapkan dapat dijadikan solusi dalam rangka penyelesaian masalah komunikasi dan koordinasi dari beberapa divisi pada BPBL Ambon.

\section{Kerangka Teori}

\subsection{Social Network Analysis}

Social network analysis mempelajari struktur hubungan yang mengaitkan individu atau unit sosial lain serta ketergantungan dalam perilaku atau sikap yang berhubungan dengan susunan hubungan sosial. Hubungan tersebut digambarkan dengan nodes dan ties (atau disebut juga edges, links atau connections). Node merupakan aktor dalam suatu jaringan, sedangkan ties adalah garis yang menghubungkan satu node dengan yang lain (O’Malley, 2008).

SNA digunakan untuk metode identifikasi pola hubungan sosial antar aktor didalam suatu jaringan sosial (Iriani, 2013). Ukuran kedekatan node satu dengan node yang lain dalam analisis jaringan adalah sentralitas (centrality). Sentralitas terbagi menjadi 
beberapa bagian namun pada penelitian ini menggunakan tiga sentralitas, yaitu : Degree Centrality, Closeness centrality, Betweness Centrality (Eriyanto, 2014)

\subsubsection{Degree Centrality}

Degree Centrality digunakan melihat tingkat popularitas suatu aktor dalam sebuah jaringan sosial, sentralitas ini berguna untuk mencari aktor yang memiliki peranan penting dalah hal kolaborasi komunikasi, hal ini ditentukan dari jumlah link dari dan ke aktor. Pada pola jaringan yang bersifat asimetris, sentralitas dapat berupa indegree (jumlah link yang mengarah ke aktor) dan outdegree (jumlah link yang keluar dari aktor), sedangkan untuk pola jaringan yang bersifat simetris, hanya terdapat satu nilai degree. Degree centrality berada pada nilai 0 hingga 1 . Angka 0 menunjukkan bahwa aktor tidak saling terhubung dengan aktor lain. Sedangkan angka 1 menunjukkan semua aktor menghubungi atau dihubungi. Berikut adalah rumus pada degree centrality:

$$
C_{d}=\sum \frac{d_{1}}{N-1}
$$

Dimana, $\mathrm{C}_{\mathrm{d}}$ merupakan degree centrality, d adalah jumlah link dari dan ke aktor dan $\mathrm{N}$ adalah jumlah anggota populasi.

\subsubsection{Closeness Centrality}

Closeness centrality digunakan untuk menggambarkan seberapa dekat aktor dengan semua aktor lain didalam jaringan sosial. Ukuran sentralitas ini penting untuk diketahui sebagai bahan pertimbangan penentuan aktor penting dalam jaringan. Kedekatan diukur dari berapa langkah atau path seorang aktor bisa menghubungi atau sebaliknya, dihubungi dari aktor lain didalam jaringan. Rumus untuk menghitung closeness centrality adalah sebagai berikut:

$$
\boldsymbol{C}_{c}=\frac{N-1}{\sum D_{i j}}
$$

Dimana, Cc merupakan closeness centrality, D adalah jalur terpendek ke aktor lain, dan $\mathrm{N}$ adalah jumlah anggota populasi. Nilai closeness centrality ialah 0 hingga 1 . Nilai closeness centrality yang semakin tinggi menunjukkan dekatnya jarak rata-rata aktor dengan semua aktor lain pada jaringan yang ada.

\subsubsection{Betweness Centrality}

Betweenness centrality digunakan untuk memperlihatkan seorang aktor sebagai perantara dari hubungan aktor satu dengan aktor lain dalam satu jaringan sosial. Sentralitas ini berfungsi untuk mencari key aktor dalam jaringan. Aktor yang mempunyai posisi sebagai perantara aktor lain bisa menentukan keanggotaan aktor lain dalam jaringan. Rumus yang digunakan pada betweenness centrality adalah sebagai berikut:

$$
\boldsymbol{C}_{b}=\frac{\frac{g_{i j} P_{k}}{g_{i j}}}{n^{2}-3 n+2}
$$

Dimana, $\mathrm{Cb}$ merupakan betweenness centrality, $\mathrm{g}_{\mathrm{ij}} \mathrm{Pk}$ jumlah jalur terpendek dari aktor, $\mathrm{g}_{\mathrm{ij}}$ merupakan jumlah jalur dalam jaringan, dan $n^{2}-3 n+2$ merupkan nilai maksimum. Nilai betweenness centrality berada pada angka 0 hingga 1.

\subsection{Balai Perikanan Budidaya Laut Ambon}

Balai Perikanan Budidaya Laut Ambon (BPBL Ambon) adalah Unit Pelaksana Teknis dari Direktorat Jenderal Perikanan Budidaya, Kementrian Kelautan dan Perikanan. Sebagai unit pelaksana teknis Direktorat Jenderal Perikanan Budidaya (DJPB), BPBL Ambon bertanggung jawab untuk menyelenggarakan uji terap teknik budidaya, produksi, pengujian laboratorium kesehatan ikan dan lingkungan serta bimbingan teknis perikanan budidaya laut. Semua hal itu dilakukan dalam rangka pembangunan perikanan di lingkup wilayah kerjanya, sesuai dengan Peraturan Menteri Kelautan dan Perikanan nomor : 6/PERMEN-KP/2014.

Dalam menjalankan tugasnya, BPBL Ambon dipimpin oleh seorang Kepala dan dibantu oleh Kepala sub bagian, Kepala seksi, serta kelompok jabatan fungsional untuk mewujudkan tercapainya visi dan misi BPBL Ambon. Lingkup wilayah kerja BPBL Ambon cukup luas yakni mencakup indonesia bagian timur, dimana wilayah kerjanya meliputi wilayah Maluku, Sulawesi, Papua dan Papua Barat. Adapun struktur organisasi BPBL AMBON tahun 2018 dapat dilihat pada gambar 1 .

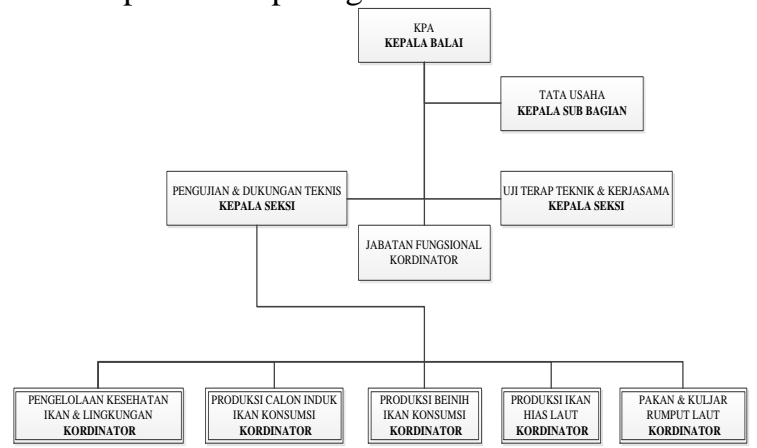

Gambar 1. Struktur organisasi BPBL Ambon

\subsection{Rujukan Pustaka}

Menurut Wu dan Duan (2015), mengukur kolaborasi dapat dianalisis menggunakan 3 ukuran sentralitias, yaitu degree centralitiy, betweenness centrality dan closeness centrality. Dimana dengan mengetahui peranan dari suatu aktor yang memiliki degree centrality yang tinggi, maka aktor tersebut dapat dianggap sebagai pusat dalam jaringan kolaborasi. Kemudian jika seorang aktor memiliki 
nilai betweenness centrality yang tinggi mengindikasikan bahwa mereka memiliki dan mengendalikan banyak sumber informasi. Sedangkan untuk closeness centrality jika suatu aktor memiliki nilai terendah, maka bisa dikatakan mereka berada pada posisi utama dari jaringan tersebut. Hal ini menjelaskan bahwa SNA mampu mengukur tingkat kolaborasi tiap aktor dari dalam jaringan sosial.

Iriani (2013) dalam penelitiannya menjelaskan bahwa dengan menggunakan 3 ukuran sentralitias, yaitu degree centrality, betweenness centrality dan closeness centrality. SNA juga mampu menganalisis dan memetakan pola tersembunyi yang ada didalam interaksi yang terjadi di suatu jaringan sosial.

Tuhuteru (2018), memberikan pendapatnya tentang penggunaan 3 ukuran sentralitias, yaitu dengan mengetahui nilai degree centrality, betweenness centrality dan closeness centrality dari suatu aktor di tambah dengan atribut yang sesuai dapat digunakan untuk mendeskripsikan hubungan kolaborasi antar aktor dalam suatu grup berdasarkan atributnya masing-masing. Dimana hasilnya dapat menunjukkan secara spesifik hubungan kolaborasi antar grup maupun hubungan kolaborasi antar perorangan.

\section{Metode}

Penelitian ini dilakukan melalui beberapa tahapan mulai dari proses identifikasi masalah yang terjadi pada BPBL Ambon, pengumpulan data, filterisasi \& tabulasi data, analisis dan pembahasan hingga pada akhrinya proses penarikan kesimpulan. Seluruh tahapan dari penelitian ini dapat dilihat pada Gambar 2 .

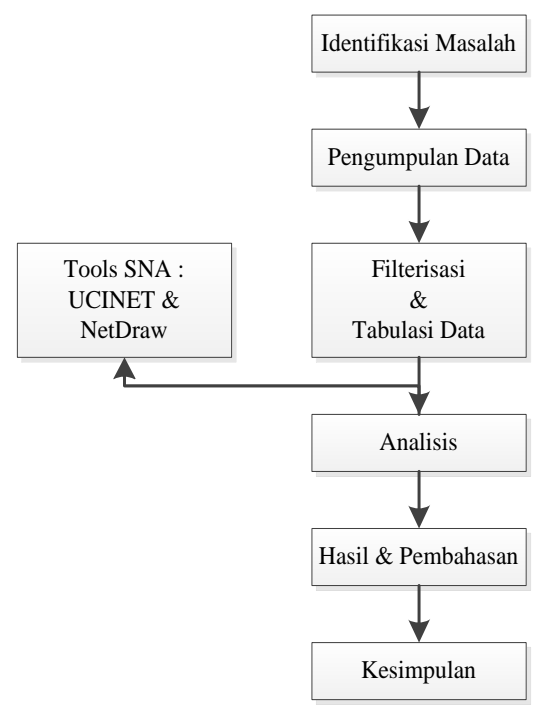

Gambar 2. Tahapan penelitian

Identifikasi Masalah: Kolaborasi Komunikasi pada BPBL ambon telah dilakukan namun tingkat kolaborasi komunikasi yang terjadi masihlah sangat kurang. Hal ini diperjelas dengan permasalahan komunikasi dan koordinasi dari beberapa divisi yang mengakibatkan terjadinya delay pencatatan barang persedian di Sistem Informasi Manajemen dan Akuntansi Barang Milik Negara (SIMAK-BMN).

Pengumpulan Data: Teknik pengumpulan data ialah saturation sampling, dimana data dikumpulkan dari seluruh individu dalam jaringan. Data berupa pola komunikasi formal dan informal dari tiap responden. Keuntungannya ialah, memungkinkan untuk mengananalisis secara rinci data dari seluruh individu yang berada dalam jaringan begitu pula dengan atribut yang menyertainya. Data dari penelitian ini terdiri dari data 84 responden dimana keseluruhannya merupakan Sumber Daya Manusia (SDM) dari BPBL Ambon.

Filterterisasi dan Tabulasi Data: Setelah dikumpulkan, data tersebut kemudian disaring dan ditabulasikan kedalam metriks simetris berdasarkan hubungan yang terjadi antar aktor.

Analisis: Data yang telah ditabulasikan kedalam bentuk metriks kemudian dianalisis menggunakan program UCINET (Borgatti et al., 2002) dan divisualisasikan dengan menggunakan program NetDraw (Borgatti, 2002). Proses analisis menggunakan metode SNA untuk mengukur sentralitas antar aktor, yaitu degree centrality, closeness centrality, betweenness centrality. Data atribut digunakan untuk mendeskripsikan hubungan kolaborasi antar aktor berdasarkan atributnya masing-masing, yaitu gender dan divisi. Validasi data sentralitas dihitung manual menggunakan Ms Excel dengan menggunakan rumus dari masing-masing sentralitas.

Hasil analisis kemudian di interpretasikan sesuai dengan nilai sentralitas antar aktor serta hubungan berdasarkan divisi.

\section{Hasil Dan Pembahasan}

Berdasakran pengolahan data yang dilakukan, diperoleh hasil sociometry dan sociogram yang dapat dilihat pada Gambar 3 dan Tabel 1.

Tabel 1. Statistik Keseluruhan Jaringan

\begin{tabular}{lc}
\hline \multicolumn{2}{c}{ Univariate Statistics } \\
\hline Observations & 6972 \\
Minimum & 0 \\
Maximum & 1 \\
Sum & 827 \\
Average & 0.119 \\
Standard Deviation & 0.323 \\
Variance & 0.105 \\
\hline
\end{tabular}

Gambar 3 merupakan visualisasi jaringan sosial atau sociogram yang memperlihatkan interaksi antar aktor satu dengan yang lain. Jumlah aktor yang ada dalam jaringan ini ialah 84, dimana node yang berbentuk lingkaran merupakan aktor pria dan node persegi merupakan aktor wanita. Pewarnaan node dilakukan berdasarkan atribut Divisi dari masing- 
masing aktor. Dimana Diketahui ada 8 divisi dalam organisasi, Node dengan warna merah untuk Kepala Balai, node warna kuning untuk divisi Pengolahan Kesehatan Ikan dan Lingkungan, node warna hijau untuk divisi Ikan Hias, node warna biru untuk divisi Pakan Alami dan Kultur Jaringan, node warna merah muda untuk divisi Produksi Benih Ikan Konsumsi, node warna orange untuk divisi Produksi Calon Induk Ikan Konsumsi, node warna coklat untuk divisi Pengujian dan Dukungan Teknis, node warna biru cyan untuk divisi Tata Usaha, dan yang terakhir node warna ungu untuk divisi Uji Terap dan Kerjasama. Diketahui pula berturut node dengan id 3, 8, 15, 36, $52,57,71$, dan 82 merupakan pemangku kepentingan dari masing-masing divisi.

Secara keseluruhan, berdasarkan Tabel 1, diperoleh informasi bahwa hubungan yang terbangun dalam jaringan berjumlah 827 dengan rata-rata hubungan yang ada sebesar 0.119 atau $11.9 \%$ yang menunjukkan presentasi hubungan dibawah 50\% maka dapat dikatakan bahwa hubungan yang terjadi dalam jaringan sosial BPBL Ambon termasuk hubungan yang lemah (Weak Ties).

\subsection{Degree Centrality}

Out-Degree Pada Tabel 2 dapat dilihat hasil dari penggunaan UCINET. Dimana dari hasil ini diperoleh informasi bahwa Aktor \#25 memiliki nilai Out-Degree tertinggi. Terlepas dari informasi apa yang diberikan dan untuk siapa informasi itu diberikan, aktor ini dapat dianggap sebagai aktor yang paling berpengaruh di seluruh jaringan. Diketahui juga aktor \#25 bukanlah salah satu dari pemangku kepentingan yang ada dalam organisasi. Hal ini menunjukkan bahwa dalam jaringan sosial aktor \#25 dapat berperan sebagai alternatif sumber informasi dari pada divisi Pakan Alami dan Kultur Jaringan.

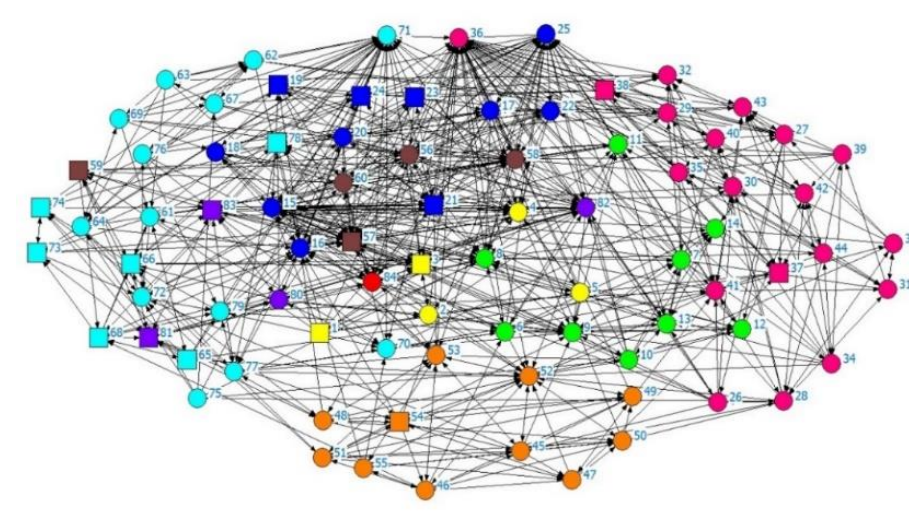

\begin{tabular}{|c|l}
\hline 0 & Aktor Pria \\
\hline$\square$ & Aktor Wanita \\
\hline & Aktor Kepala Balai \\
\hline 0 & Aktor dari Devisi Pengolahan Kesehatan Ikan dan Lingkungan \\
\hline 0 & Aktor dari Devisi Ikan Hias \\
\hline & Aktor dari Devisi Pakan Alami dan Kultur Jaringan \\
\hline$\square$ & Aktor dari Devisi Produksi Benih Ikan Konsumsi \\
\hline 0 & Aktor dari Devisi Produksi Calon Induk Ikan Konsumsi \\
\hline 0 & Aktor dari Devisi Pengujian dan Dukungan Teknis \\
\hline $0 \square$ & Aktor dari Devisi Tata Usaha \\
\hline $0 \square$ & Aktor dari Devisi Uji Terap dan Kerjasama \\
\hline
\end{tabular}

Gambar 3 : Sociogram dari BPBL Ambon.

Tabel 2.Nilai Degree Centrality Untuk Beberapa Aktor

\begin{tabular}{cccccc}
\hline No. & ID & OutDegree & InDegree & NrmOutDeg & NrmInDeg \\
\hline 1 & 25 & 22 & 23 & 26.506 & 27.711 \\
2 & 21 & 19 & 13 & 22.892 & 15.663 \\
3 & 15 & 19 & 33 & 22.892 & 39.759 \\
4 & 22 & 17 & 6 & 20.482 & 7.229 \\
5 & 57 & 16 & 26 & 19.277 & 31.325 \\
6 & 16 & 15 & 24 & 18.072 & 28.916 \\
7 & 17 & 14 & 9 & 16.867 & 10.843 \\
8 & 23 & 14 & 6 & 16.867 & 7.229 \\
9 & 20 & 14 & 7 & 16.867 & 8.434 \\
10 & 36 & 11 & 49 & 13.253 & 59.036 \\
\hline
\end{tabular}

In-Degree Pada Tabel 2, aktor \#36 ialah aktor yang memiliki nilai In-degree tertinggi hal ini menunjukkan bahwa aktor \#36 merupakan aktor yang paling dikenal dan diakui dalam jaringan. Terlepas dari informasi apa yang diterima dan dari siapa informasi itu diterima, aktor ini dapat dianggap sebagai aktor yang memiliki kesediaan informasi untuk aktor lain dalam jaringan. Kesediaan mereka menunjukkan tindakan pengakuan atau penghormatan terhadap posisi aktor.
NrmDegOut dan NrmInDeg menunjukkan normalisasi Degree Centrality, yaitu Degree Centrality dibagi dengan jumlah aktor dalam jaringan dikurangi satu $(84-1=83)$. Normalisasi Out-Degree (NrmOutDeg) dari Aktor \#25 adalah 26\%, sementara normalisasi In-Degree (NrmInDeg) dari aktor \#36 adalah $59 \%$.

Statistik deskriptif dari degree centrality ditunjukkan pada tabel 3. Rata-rata dari nilai degree secara keseluruhan didalam jaringan, yaitu 9.845. 
Jika dibagi per aktor, maka dapat dikatakan masingmasing aktor pada jaringan memiliki kira-kira 9 link. Minimum dan Maximum menunjukkan nilai terendah dan nilai tertinggi pada degree centrality, Jumlah koneksi maksimum ke luar (out-degree) dalam jaringan ini adalah 22 yang dimiliki oleh aktor \#25, sedangkan jumlah minimum ke luar (out-degree) adalah 6. Selain itu untuk koneksi maksimum dari hubungan yang masuk (in-degree) nilai maksimumnya adalah 49 yang dimiliki oleh aktor \#36 dan nilai minimum hubungan yang masuk (in-degree) adalah 0 . Ini berarti bahwa ada aktor yang hanya memberikan informasi tetapi tidak menerima informasi dari pihak lain.

Dari nilai sentralisasi OutDegree dan nilai sentralisasi InDegree dari jaringan sosial yang berturut sebesar $15 \%$ dan $47 \%$, nilai sentralisasi untuk InDegree jauh lebih tinggi dari nilai sentralisasi untuk OutDegree. Ini menunjukkan bahwa dalam jaringan ini ada kepincangan komunikasi dalam hal kolaborasi informasi, aktor lebih suka menerima daripada memberikan informasi. Dengan kata lain, jumlah aktor yang menerima informasi lebih dari jumlah aktor yang memberikan informasi.

Pada Gambar 4 dapat terlihat dengan jelas sociogram berdasarkan Degree Centrality keseluruhan aktor pada jaringan. Aktor \#25 dengan out-degree centrality tertinggi merupakan aktor pria yang berasal dari divisi Pakan Alami dan Kultur Jaringan. Sedangkan aktor \#36 yang memiliki nilai in-degree centrality tertinggi merupakan aktor pria yang berasal dari divisi Produksi Benih Ikan Konsumsi.

Tabel 3.Statistik Deskriptif Dari Degree Centrality

\begin{tabular}{|c|c|c|c|c|c|}
\hline & & OutDegree & InDegree & NrmOutDeg & NrmInDeg \\
\hline 1 & Mean & 9.845 & 9.845 & 11.862 & 11.862 \\
\hline 2 & Std Dev & 2.982 & 8.257 & 3.593 & 9.948 \\
\hline 3 & Sum & 827 & 827 & 996.386 & 996.386 \\
\hline 4 & Variance & 8.893 & 68.178 & 12.909 & 98.967 \\
\hline 5 & SSQ & 8889 & 13869 & 12903.18 & 20132.09 \\
\hline 6 & MCSSQ & 746.988 & 5726.988 & 1084.32 & 8313.235 \\
\hline 7 & Euc Norm & 94.281 & 117.767 & 113.592 & 141.888 \\
\hline 8 & Minimum & 6 & 0 & 7.229 & 0 \\
\hline 9 & Maximum & 22 & 49 & 26.506 & 59.036 \\
\hline 10 & $\mathrm{~N}$ of Obs & 84 & 84 & 84 & 84 \\
\hline
\end{tabular}

Network Centralization (Outdegree) $=14.821 \%$

Network Centralization (Indegree) $=47.743 \%$

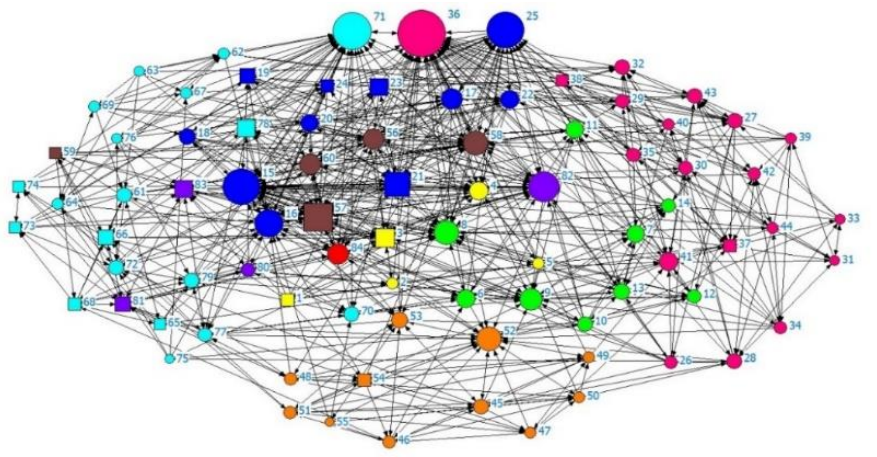

Gambar 4. Sociogram berdasarkan degree centrality dari jaringan sosial.

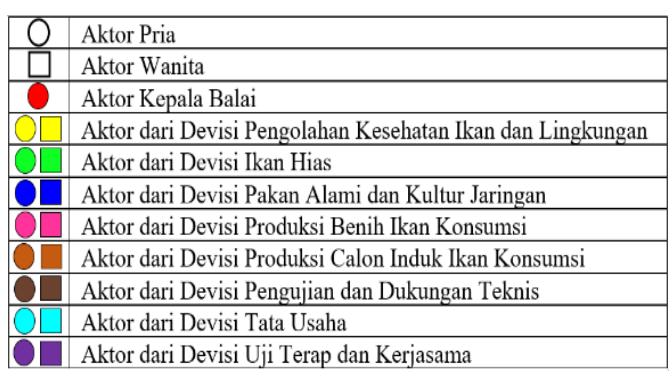

Outcloseness menunjukkan kedekatan seorang aktor dengan aktor lain dalam jaringan. Incloseness dan Outcloseness berbeda karena ada hubungan asimetris dalam mengirim dan menerima informasi. Dari Tabel 4, aktor \#36 memiliki Inclosesness tertingi yaitu 66 dan aktor \#25 memiliki nilai tertinggi untuk Outcloseness sebesar 48.1 Angka-angka ini menunjukkan bahwa aktor \#36 dan aktor \#25 memiliki kedekatan dengan aktor lain atau aktor lain dapat dengan mudah menjangkau posisinya dalam

jaringan. Hal ini menjelaskan bahwa, dari nilai
Pada Tabel 4, Incloseness menunjukkan jarak dari aktor lain dalam jaringan ke aktor. Sedangkan

\section{Clossness Centrality}

informasi dalam jaringan. Pengukuran kedekatan berbeda dari pengukuran tingkat sentralitas. Degree Centrality hana memperhitungkan hubungan mengabaikan hubungan tidak langsung dengan semua aktor lainnya. Closeness centrality menghitung jarak dari aktor ke semua aktor lain dalam jaringan. 
Inclosesness aktor \#36 memiliki posisi yang disukai di jaringan, karena aktor ini dapat dihubungi dengan mudah atau lebih cepat. Sedangkan nilai
Outcloseness tertinggi ialah aktor \#25, artinya aktor ini punya kecendrungan untuk menjangkau aktor lain dengan cepat dalam jaringan sosial.

Tabel 4.Nilai Clossness Centrality untuk beberapa aktor

\begin{tabular}{llllll}
\hline No. & ID & inCloseness & outCloseness & NinCloseness & NoutCloseness \\
\hline 1 & 36 & 66 & 42.083 & 79.518 & 50.703 \\
2 & 71 & 60.333 & 38.95 & 72.691 & 46.928 \\
3 & 15 & 58 & 45.6 & 69.88 & 54.94 \\
4 & 57 & 54.5 & 44.917 & 65.663 & 54.116 \\
5 & 82 & 53.833 & 39.417 & 64.859 & 47.49 \\
6 & 52 & 53 & 39.1 & 63.855 & 47.108 \\
7 & 16 & 52.833 & 40.6 & 63.655 & 48.916 \\
8 & 25 & 51.833 & 48.1 & 62.45 & 57.952 \\
9 & 8 & 51.5 & 39.3 & 62.048 & 47.349 \\
10 & 9 & 50 & 34.717 & 60.241 & 41.827 \\
\hline
\end{tabular}

Tabel 5. Statistik deskriptif dari Clossness Centrality.

\begin{tabular}{rlrrrr}
\hline & inCloseness & outCloseness & NinCloseness & NoutCloseness \\
\hline 1 & Mean & 39.017 & 39.017 & 47.009 & 47.009 \\
2 & Std Dev & 9.148 & 2.54 & 11.021 & 3.06 \\
3 & Sum & 3277.45 & 3277.45 & 3948.735 & 3948.735 \\
4 & Variance & 83.677 & 6.45 & 121.465 & 9.363 \\
5 & SSQ & 134906 & 128418.9 & 195828.1 & 186411.563 \\
6 & MCSSQ & 7028.861 & 541.786 & 10203.02 & 786.451 \\
7 & Euc Norm & 367.296 & 358.356 & 442.525 & 431.754 \\
8 & Minimum & 0 & 33.85 & 0 & 40.783 \\
9 & Maximum & 66 & 48.1 & 79.518 & 57.952 \\
10 & N of Obs & 84 & 84 & 84 & 84 \\
\hline
\end{tabular}

Network in-Centralization $=66.20 \%$

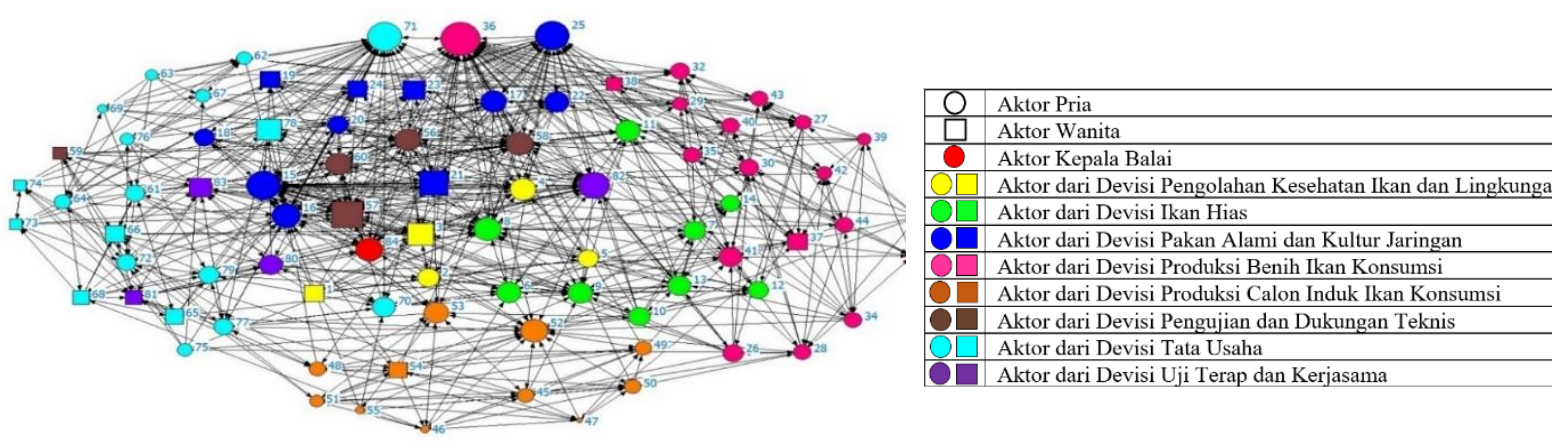

Gambar 5. Sociogram Berdasarkan Clossness Centrality dari Jaringan Sosial.

Dari hasil statistik Tabel 5, dapat dilihat bahwa Incloseness centrality memiliki nilai yang jauh berbeda dengan nilai Out-closeness centrality sebagaimana di indikasikan oleh jaringan In-closeness centrality bernilai $(66,20 \%)$ dan jaringan Out-closeness centrality $(22,28 \%)$. Ini berarti ada ketidak seimbangan jarak antara satu aktor ke aktor lain, juga jarak antar aktor lain dengan aktor tertentu dalam jaringan. Gambar 5 menunjukkan Sociogram berdasarkan Clossness Centrality. Ukuran dari node sebanding dengan nilai-nilai Clossness Centrality dari masing-masing aktor.
Pada Gambar 5 dapat terlihat dengan jelas sociogram berdasarkan Clossness Centrality keseluruhan aktor pada jaringan. Diketahui aktor \#25 dengan Out-closeness centrality tertinggi merupakan aktor pria yang berasal dari divisi Pakan Alami dan Kultur Jaringan. Sedangkan aktor \#36 yang memiliki nilai In-closeness centrality tertinggi merupakan aktor pria yang berasal dari divisi Produksi Benih Ikan Konsumsi. Kemudian dari 10 aktor dengan nilai Clossness Centrality tertinggi. selain aktor \#25 dan aktor \#9, 8 aktor lainnya merupakan aktor yang dapat dikategorikan sebagai pemangku kepentingan dalam 
jaringan karena menjabat sebagai kordinator dari setiap divisi. Mulai dari aktor \#36 merupakan kordinator dari divisi Pakan Alami dan Kultur Jaringan, aktor \#71 merupakan aktor pria yang juga menjabat kordinator divisi Tata Usaha, aktor \#15 merupakan aktor pria yang juga menjabat kordinator divisi Pakan Alami dan Kultur Jaringan, aktor \#57 merupakan aktor wanita yang juga menjabat kordinator divisi Pengujian Dukungan Teknis, aktor \#82 merupakan aktor pria yang juga menjabat kordinator divisi Uji Terap dan Kerjasama, aktor \#52 merupakan aktor pria yang juga menjabat kordinator divisi Produksi Calon Induk Ikan Konsumsi, aktor \#16 merupakan aktor pria yang juga menjabat kordinator Jabatan Fungsional, aktor \#8 merupakan aktor pria yang juga menjabat kordinator divisi Ikan Hias.

\subsection{Betweenness Centrality}

Betweenness centrality merupakan pengukuran posisi sejauh mana seorang aktor disukai posisinya untuk dijadikan jalur antara pasangan aktor lain dalam jaringan. Dengan kata lain, semakin banyak orang bergantung pada seorang aktor untuk membuat koneksi dengan orang lain, semakin banyak kekuatan yang dimiliki sang aktor.

Hasil pengukuran betweenness centrality dari 10 aktor dengan nilai tertinggi dari jaringan kolaborasi ditunjukkan pada Tabel 6 .

Tabel 6. Nilai Betweenness Centrality untuk beberapa aktor

\begin{tabular}{lccc}
\hline No & ID & Betweenness & nBetweenness \\
\hline 1 & 36 & 821.795 & 12.075 \\
2 & 25 & 474.88 & 6.977 \\
3 & 15 & 449.182 & 6.6 \\
4 & 52 & 357.738 & 5.256 \\
5 & 32 & 342.46 & 5.032 \\
6 & 71 & 331.01 & 4.864 \\
7 & 57 & 316.834 & 4.655 \\
8 & 82 & 277.813 & 4.082 \\
9 & 16 & 271.173 & 3.984 \\
10 & 8 & 246.666 & 3.624 \\
\hline
\end{tabular}

Berdasarkan hasil dari tabel tersebut, diketahui bahwa aktor \#36 dari divisi Produksi Benih Ikan Konsumsi memiliki nilai betweenness centrality yang tinggi, yaitu 821.795. Kemudian diikuti oleh aktor \#25 dan \#15 yang sama-sama dari divisi Pakan Alami dan Kultur Jaringan dengan nilai betweenness masing-masing 474.88 dan 449.182. Hal ini mengindikasikan bahwa aktor-aktor ini merupakan aktor favorit didalam jaringan karena memiliki kemampuan untuk menjadi perantara atau penghubung antar aktor pada jaringan kolaborasi informasi seperti yang terlihat pada Tabel 6. Fakta ini juga menunjukkan bahwa aktor-aktor ini yang paling banyak melakukan kolaborasi dengan aktor lain.

Tabel 7.Statistik Betweenness Centrality

\begin{tabular}{llrr}
\hline & & Betweenness & nBetweenness \\
\hline 1 & Mean & 118.179 & 1.736 \\
2 & Std Dev & 127.716 & 1.877 \\
3 & Sum & 9927 & 145.857 \\
4 & Variance & 16311.37 & 3.521 \\
5 & SSQ & 2543313 & 549.055 \\
6 & MCSSQ & 1370155 & 295.792 \\
7 & Euc Norm & 1594.777 & 23.432 \\
8 & Minimum & 0 & 0 \\
9 & Maximum & 821.795 & 12.075 \\
10 & N of Obs & 84 & 84 \\
\hline
\end{tabular}

Network Centralization Index $=10.46 \%$

Dari hasil Statistik deskriptif dari betweenness centrality ditunjukkan pada tabel 7 . Nilai rata-rata dari betweenness Centrality secara keseluruhan didalam jaringan, yaitu 118.179. Nilai Minimum dan Maximum menunjukkan nilai terendah dan nilai tertinggi pada betweenness Centrality, yaitu masingmasing 0 dan 821.795. Jumlah aktor yang diteliti adalah 84 , sedangkan jumlah total nilai betweeness, yaitu sebesar 9927 yang dinormalisasikan menjadi 145.857. Sentralisasi jaringan sosial pada betweenness centrality, yaitu sebesar $10.46 \%$ dimana hal ini menggambarkan hubungan secara keseluruhan pada jaringan yang rendah diantara sesama aktor dalam hubungannya sebagai perantara. Gambar 6 menunjukkan Sociogram berdasarkan Betweenness Centrality. Ukuran dari node sebanding dengan nilainilai betweenness centrality dari masing-masing aktor.

Pada Gambar 6 dapat terlihat dengan jelas sociogram berdasarkan Betweenness Centrality dari keseluruhan aktor pada jaringan. Diketahui bahwa aktor \#25 dari divisi Produksi Benih Ikan Konsumsi memiliki nilai betweenness centrality yang tinggi. Pada hasil sociogram ini pula aktor \#25 digambarkan dengan ukuran node yang besar untuk memperjelas pengaruh dari aktor \#25 dalam perannanya sebagai perantara dan menjadi aktor favorit dalam melakukan kolaborasi informasi. 


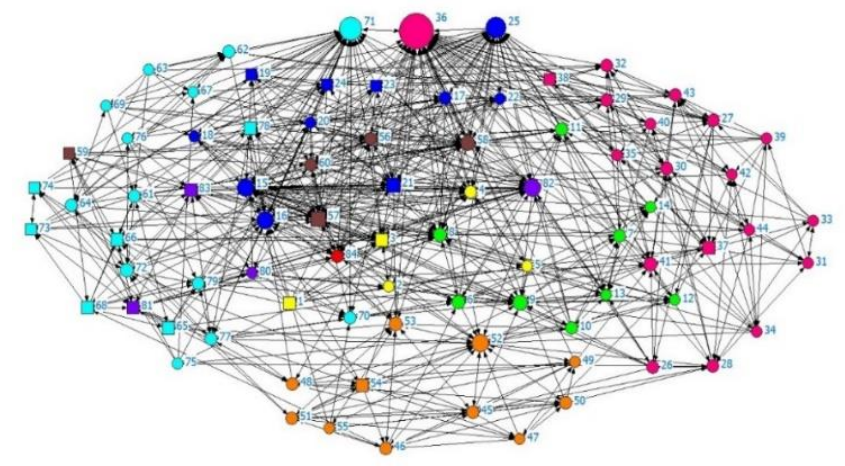

\begin{tabular}{|c|l|}
\hline 0 & Aktor Pria \\
\hline$\square$ & Aktor Wanita \\
\hline 0 & Aktor Kepala Balai \\
\hline 0 & Aktor dari Devisi Pengolahan Kesehatan Ikan dan Lingkungan \\
\hline 0 & Aktor dari Devisi Ikan Hias \\
\hline 0 & Aktor dari Devisi Pakan Alami dan Kultur Jaringan \\
\hline 0 & Aktor dari Devisi Produksi Benih Ikan Konsumsi \\
\hline 0 & Aktor dari Devisi Produksi Calon Induk Ikan Konsumsi \\
\hline 0 & Aktor dari Devisi Pengujian dan Dulkungan Teknis \\
\hline 0 & Aktor dari Devisi Tata Usaha \\
\hline 0 & Aktor dari Devisi Uji Terap dan Kerjasama \\
\hline
\end{tabular}

Gambar 6. Sociogram berdasarkan Betweenness Centrality dari jaringan sosial.
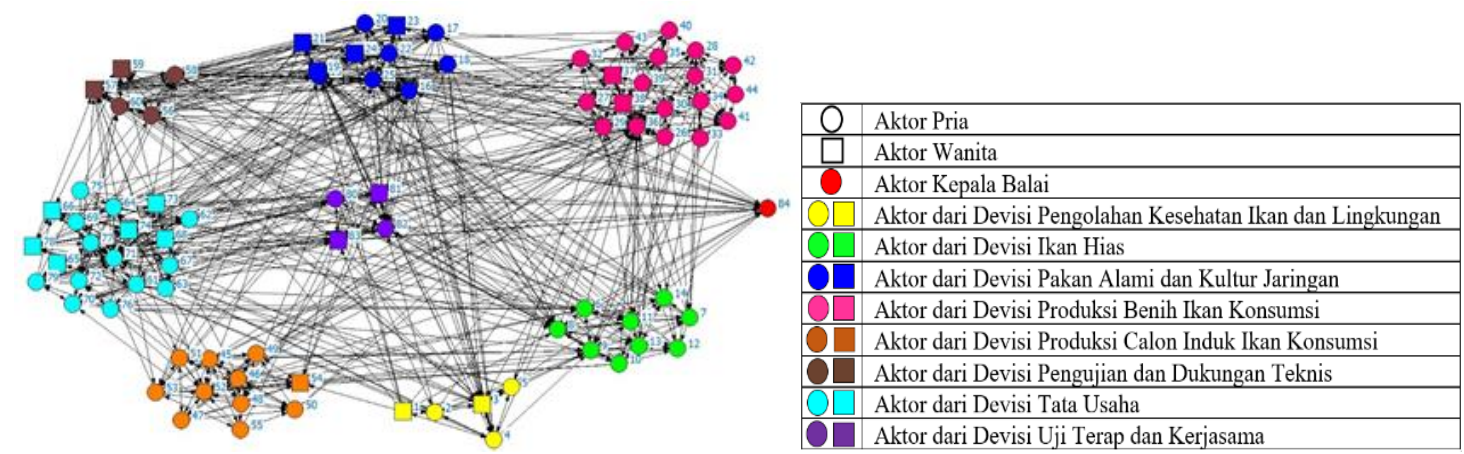

Gambar 7. Sociogram berdasarkan divisi dari masing-masing aktor

\subsection{Relasi Berdasarkan Divisi}

Hubungan antar aktor berdasarkan atribut divisi ditunjukan pada Tabel 8 dan Gambar 6. Node dengan warna merah dan id \#0 untuk Kepala Balai, node warna kuning dan id\#1 untuk divisi Pengolahan Kesehatan Ikan dan Lingkungan, node warna hijau dan id \#2 untuk divisi Ikan Hias, node warna biru dan id \#3 untuk divisi Pakan Alami dan Kultur Jaringan, node warna merah muda dan id \#4 untuk divisi Produksi Benih Ikan Konsumsi, node warna orange dan id \#5 untuk divisi Produksi Calon Induk Ikan Konsumsi, node warna coklat dan id \#6 untuk divisi Pengujian dan Dukungan Teknis, node warna biru cyan dan id \#7 untuk divisi Tata Usaha, dan yang terakhir node warna ungu dan id \#8 untuk divisi Uji Terap dan Kerjasama.
Berdasarkan tabel 8, diketahui konsentrasi kolaborasi informasi yang dilakukan berasal dari Divisi Pakan Alami dan Kultur Jaringan dan Divisi Pengujian dan Dukungan Teknis. Kolaborasi diantara kedua divisi ini juga yang terbanyak diantara kolaborasi antar divisi yang lain, yaitu berjumlah 31. Selain itu, Divisi Produksi Benih Ikan Konsumsi juga menarik perhatian karena merupakan divisi yang memiliki jumlah link terbanyak untuk hubungan keluar maupun hubungan dari luar. Artinya divisi ini punya pengaruh yang besar dalam hal melakukan kolaborasi dengan aktor-aktor dalam jaringan dibandingkan dengan divisi-divisi yang lain. Kolaborasi ini dapat dilihat secara visual pada Gambar 7.

Tabel 8. Jumlah link berdasarkan divisi

\begin{tabular}{ccccccccc}
\hline ID_Divisi & 1 & 2 & 3 & 4 & 5 & 6 & 7 & 8 \\
\hline 1 & 19 & 5 & 3 & 5 & 1 & 2 & 9 & 2 \\
2 & 0 & 51 & 16 & 11 & 6 & 4 & 0 & 3 \\
3 & 12 & 6 & 77 & 6 & 6 & 31 & 11 & 11 \\
4 & 2 & 13 & 19 & 111 & 6 & 4 & 5 & 3 \\
5 & 0 & 3 & 6 & 7 & 65 & 1 & 6 & 3 \\
6 & 4 & 7 & 6 & 4 & 2 & 20 & 6 & 3 \\
7 & 1 & 8 & 15 & 14 & 5 & 12 & 83 & 19 \\
8 & 2 & 5 & 0 & 4 & 2 & 4 & 11 & 12 \\
\hline
\end{tabular}

Berdasarkan tabel 8, Walaupun sebagian besar divisi telah melakukan kolaborasi komunikasi namun ada beberapa divisi yang memiliki nilai 0 dalam hubungan kolaborasi komunikasi artinya masingmasing divisi tidak melakukan kolaborasi sama sekali. Hal ini jelas menunjukan letak permasalahan 
komunikasi dan koordinasi dari BPBL Ambon. Dari tabel 8 dapat diketahui bahwa ada beberapa divisi yang perlu meningkatkan kolaborasi komunikasi diantaranya ialah : Divisi Ikan Hias terhadap Divisi Pengolahan Kesehatan Ikan Dan Lingkungan dan Divisi Tata Usaha, kemudian Divisi Produki Calon Induk Ikan Konsumsi terhadap Divisi Pengolahan Kesehatan Ikan Dan Lingkungan.

\subsection{Aktor Alternatif Tiap Divisi}

Permasalahan komunikasi dan koordinasi antar divisi pada BPBL Ambon disebabkan karena kurangnya kolaborasi komunikasi antar beberapa divisi dan delay informasi dari pemangku kepentingan, untuk menyelesaikan permasalahan ini diperlukan sumber informasi alternatif dari tiap divisi dalam rangka akses informasi. Mencari aktor yang dapat dijadikan alternatif sumber informasi dari tiap divisi selain aktor pemangku kepentingan perlu dilakukan sorting nilai indegree dari tiap aktor dalam jaringan. Nilai indegree sendiri merupakan jumlah koneksi dari luar ke dalam, nilai ini menunjukkan posisi aktor sebagai penerima informasi dari luar, terlepas dari informasi apa yang diterima dan dari siapa informasi tersebut diterima. Aktor yang memiliki nilai indegree tinggi merupakan aktor yang bisa dikatakan mempunyai ketersedian informasi untuk aktor lain dalam jaringan. Aktor yang memiliki nilai indegree tertinggi kedua setelah pemangku kepentingan dengan dukungan nilai betweenness centrality yang tinggi diyakini dapat menjadi alternatif sumber informasi dikarenakan, aktor dengan nilai betweenness centrality yang tinggi memiliki peran penting dalam sebuah jaringan karena berperan sebagai penghubung dua kelompok jaringan yang berbeda, dapat mengontrol informasi, dan juga memanipulasi informasi (Eriyanto, 2014). Hasil sorting nilai indegree dan betweenness centrality untuk alternatif aktor dari tiap divisi dapat dilihat pada Tabel 9.

Tabel 9. Aktor alternatif dari tiap divisi berdasarkan nilai indegree.

\begin{tabular}{cccc}
\hline Id_Divisi & Id_Aktor & InDegree & Betweenness \\
\hline 1 & 4 & 13 & 104.839 \\
2 & 9 & 21 & 144.046 \\
3 & 16 & 24 & 271.173 \\
4 & 41 & 13 & 167.766 \\
5 & 53 & 12 & 188.114 \\
6 & 58 & 19 & 128.467 \\
7 & 66 & 10 & 153.598 \\
8 & 83 & 12 & 245.579 \\
\hline
\end{tabular}

Dari Tabel 9 dapat dilihat hasil sorting nilai indegree dan betweenness centrality untuk tiap aktor, diketahui bahwa Aktor \#4 dapat dijadikan aktor alternatif dalam rangka akses infromasi dari id divisi \#1 yaitu divisi Pengolahan Kesehatan Ikan dan Lingkungan, Aktor \#9 dapat dijadikan aktor alternatif dalam rangka akses infromasi dari id divisi \#2 yaitu divisi Ikan Hias, Aktor \#16 dapat dijadikan aktor alternatif dalam rangka akses infromasi dari id divisi \#3 yaitu divisi Pakan Alami dan Kultur Jaringan, Aktor \#41 dapat dijadikan aktor alternatif dalam rangka akses infromasi dari id divisi\#4 yaitu divisi Produksi Benih Ikan Konsumsi, Aktor \#53 dapat dijadikan aktor alternatif dalam rangka akses infromasi dari id divisi \#5 yaitu divisi Produksi Calon Induk Ikan Konsumsi, Aktor \#58 dapat dijadikan aktor alternatif dalam rangka akses infromasi dari id divisi \#6 yaitu divisi Pengujian dan Dukungan Teknis, Aktor \#66 dapat dijadikan aktor alternatif dalam rangka akses infromasi dari id divisi \#7 yaitu divisi Tata Usaha, dan yang terakhir Aktor \#83 dapat dijadikan aktor alternatif dalam rangka akses infromasi dari id divisi \#8 yaitu divisi Uji Terap dan Kerjasama.

Dengan informasi ini permasalahan komunikasi dan koordinasi antar tiap divisi dapat di minimalisir. Karena, bila delay kebutuhan informasi dari suatu divisi dikarenakan kurangnya koneksi terhadap pemangku kepentingan yang merupakan sumber informasi utama dari divisi tersebut dapat dicegah dengan menghubungi aktor alternatif dalam rangka mengakses informasi dari divisi tersebut. Sehingga dalam rangka penyelesaian tugas pencatatan hanya perlu mengecek informasi dari alternatif aktor tidak perlu sampai melakukan pengecekan rutin maupun berkala terhadap aktor pemangku kepentingan dalam hal ini kordinator/kepala divisi.

\subsection{Generalisasi}

Setelah dilakukan analisis kolaborasi komunikasi terhadap pola komunikasi pada jaringan sosial BPBL Ambon, metode ini dapat digeneralisasi terhadap kasus-kasus yang terdapat pada kelompok jaringan sosial lain. Metode ini dapat diterapkan pada kasuskasus dengan kriteria sebagai berikut :

- Terdiri dari Individu (aktor) atau kelompok (grup) yang memiliki hubungan satu dengan yang lain sehingga dapat untuk mengukur tingkat kolaborasi.

- Setiap aktor dalam hubungannya memiliki informasi yang berbeda dengan aktor lainnya.

- Adanya pertukaran informasi antar aktor sehingga dapat dilihat seberapa besar tingkat kolaborasi antar aktor serta seberapa penting peran aktor dan pengaruhnya terhadap penyebaran sebuah informasi dalam jaringan komunikasi.

Pada Gambar 8 merupakan keseluruhan dari aktivitas analisa kolaborasi komunikasi pada BPBL Ambon menggunakan SNA, Proses ini dapat memperlihatkan adanya kekurangan kolaborasi dari beberapa divisi serta proses pencarian aktor alternatif yang merupakan solusi yang direkomendasikan dari hasil penelitian. 


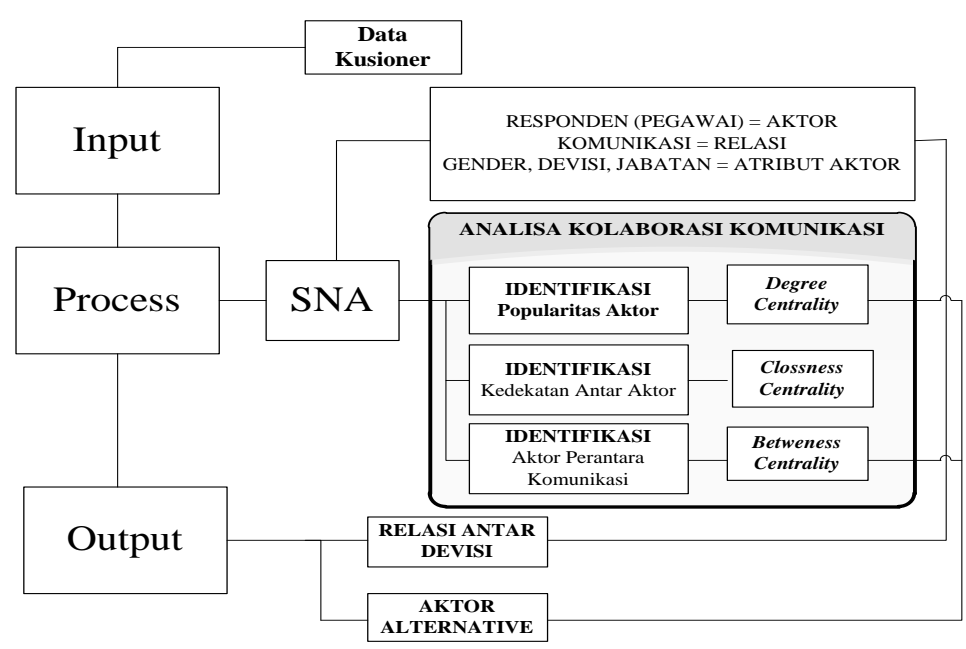

Gambar 8. Mind Mapping aktivitas analisa kolaborasi komunikasi

\section{Kesimpulan dan Saran}

Proses Analisis pola interaksi menggunakan SNA pada BPBL Ambon, tidak hanya dapat menunjukan secara umum kekurangan pada kolaborasi informasi namun juga memberikan informasi lebih lengkap terkait seberapa besar kepincangan dari kolaborasi informasi yang ada dalam jaringan. Serta, dengan penggunaan atribut dari setiap aktor Analisis ini dapat menjleaskan secara khusus kekurangan kolaborasi antar divisi.

Hasil analisis Pola interaksi dari penelitian ini dapat digunakan oleh Pihak BPBL Ambon untuk melakukan penilaian serta peningkatan dalam hal kolaborasi komunikasi. Hasil Analisis data diperoleh bahwa kepincangan kolaborasi komunikasi diakibatkan oleh tidak seimbangnya presentasi nilai sentralisasi jaringan. Dimana, nilai InDegree jauh lebih tinggi dari pada nilai OutDegree yang mana Nilai InDegree bernilai $47 \%$ dan OutDegree bernilai $15 \%$.

Permasalahan Komunikasi dan koordinasi dari beberapa divisi secara spesifik ditemukan berdasarkan hasil analisis relasi antar divisi. Dimana, diketahui ada beberapa divisi yang memiliki nilai 0 dalam hal hubungan kolaborasi komunikasi. Artinya dengan data atribut yang sesuai dari masing-masing aktor, dapat mengukur serta melihat keberadaan koneksi antar aktor yang telah dikelompokan ke dalam grup sesuai dengan atributnya. Sehingga data atribut memiliki peranan penting dalam hal mencari koneksi tersembunyi dalam kelompok maupun antar kelompok di dalam jaringan sosial.

Dari temuan ini diperlukan alternatif aktor sebagai solusi, Alternatif aktor didapat dari hasil sorting nilai indegree dan betweenness centrality tertinggi kedua setelah stakeholder/pemangku kepentingan dari seluruh aktor dalam divisi. Alternatif aktor diharapkan dapat menjadi alternatif sumber informasi dari tiap divisi. Alternatif aktor merupakan upaya penyelesaian masalah kurangnya kolaborasi komunikasi antar divisi pada jaringan sosial BPBL Ambon. Aktor \#4 dari Divisi Pengelolaan Kesehatan Ikan Dan Lingkungan dan aktor \#66 dari Divisi Tata Usaha dapat dijadikan alternatif aktor untuk permasalah hubungan komunikasi dari Divisi Ikan Hias dan Divisi Produksi Calon Induk Ikan Konsumsi dalam hal mencari informasi dari Divisi Pengelolaan Kesehatan Ikan Dan Lingkungan dan Divisi Tata usaha.

\section{Daftar Pustaka}

Balai Perikanan Budidaya Laut Ambon, 2017. Rencana Strategis Perubahan Balai Perikanan Budidaya Laut Ambon Tahun 2017-2019. [Online]. Website: http://bpblambon-kkp.org/wpcontent/uploads/2017/05/Rencana-Strategis-

Perubahan-BPBLA-2017-2019.pdf, Diakses tanggal 5october 2018.

Balai Perikanan Budidaya Laut Ambon, 2017. Laporan Sistem Pengendalian Intern Pemerintah (SPIP) Triwulan III. [Online]. Website : http://bpblambon-kkp.org/wpcontent/uploads/2017/11/Laporan-SPIP-TW-32017.pdf. Diakses tanggal 5 october 2018.

Borgatti, S.P., Everett, M.G. and Freeman, L.C., 2002. UCINET 6 for Windows: Software for social network analysis (Version 6.102), Harvard, MA: Analytic Tecnologies. $10-47$.

Borgatti, S.P., 2002. NetDraw Software for Network Visualization. Analytic Technologies: Lexington, KY

Eriyanto, 2014. Analisis Jaringan Komunikasi : Strategi Baru Dalam Penelitian Ilmu Komunikasi Dan Ilmu Sosial Lainnya. Kencana Prendada Media Group. Jakarta.

Iriani, A., 2013. Using social network analysis to analyze collaboration in batik smes, Journal of 
Knowledge Management, Economics and Information Technology., vol. 3, no. 6, 2-18.

Muhamad, R., Bungin, B., 2015. Audit Komunikasi Pendekatan dan Metode Asesmen Sistem Informasi Komunikasi Dalam Organisasi, Prenada Media Group, Jakarta. 82-85

Muhammad, A., 1995. Komunikasi Organisasi, Bumi Aksara, Jakarta, 67-102.

O’Malley, A.J., Marsden, P.V., 2008. The analysis of social networks, Health Serv Outcomes Res Method, Springer, 222-269.

Pengestu, M., 2015. Jaringan Komunikasi di The Piano Institute Surabaya, E- Komunikasi vol. 3, Univ. Kristen Petra Surabaya, 1-12.

Salamati, P., Soheili, F., 2016. Social network analysis of Iranian researchers in the field of violence. Chinese Jurnal of Traumatology. vol. 19, ScienceDirect, 264-270.
Soemirat, S., Ardianto, E., Suminar, Y.R., 2016. Komunikasi organisasional In: Dasar-dasar Komunikasi Organisasional: Pengertian, Ruang Lingkup, dan Peranan Komunikasi. Universitas Terbuka, Jakarta, 1-6.

Tsvetovat, M., Kouznetsov, A., 2011. Social Network Analysis for Startups. O'reilly Media. California, United States of America. 10-185

Tuhuteru, H., Iriani, A., 2018. Analisis Kolaborasi Penelitian Ilmiah Dosen Fakultas X dengan Social Network Analysis,Jurnal Teknik Informatika dan Sistem Informasi, Vol 4. Bandung. 149-158.

Wu, Y., Duan, Z., 2015. Social network analysis of international scientific collaboration on psychiatry research. International Journal of mental health system, Vol 9. Article Number 2. 110 